\title{
The Impact of International Businesses in a Global Economy: An Interdisciplinary Analysis
}

\author{
Grace Malachi Brown, $\mathrm{PhD}$ \\ Department Of History And Diplomatic Studies, Faculty Of Humanities, Rivers State University Of Education, \\ P. M. B. 5047, Rumuolumeni, Port Harcourt, Rivers State, Nigeria
}

\begin{abstract}
This study is an analysis of the impact of international businesses in the world economy. It examined the effect of globalization in the economic growth of international businesses and the world economy; and the organizations that act as alliances in international business, such as the World Trade Organization and the International Monetary Fund. The study observed that while some countries may be favoured by particular changes in international business, others may be adversely affected. This does not mean that international business does not have unfavorable effects. Major changes in international business will also produce major adjustments. The process of adjustments may be a gainful one. The study concludes that in spite of the national economic policies of each country, politics and law play important role in international business, which does not tend to restrict its views to the interest of one country, but it tries to analyze the different national interests which are relevant to the national level of decision-making.
\end{abstract}

\section{Introduction}

With the passage of time there will be many changes globally that would affect the economy of many countries. Globalization was one of the major changes that the world witnessed recently, and similar to this kind of major make over, there are expected to be more isolated yet more effective changes made.

Sussman (1997) observed that in the last 10-15 years, trade has been major changes. These changes are ones that directly affect the lives of the working class, and have raised a great deal of concern for millions of people. This is because of the fact that democratic principles might well be overwhelmed by capitalist endeavors. However, from a governmental perspective it appears that these strategies are ones that would not interfere with democracy. It seems that the government believes that the alliances would aid the effect of globalization, thereby creating better trade in North Western hemisphere. According to Gbosi (1999), there is whole set of national policies in every country. These policies are always designed to serve some part of national constituency. As international business or trade involves flows across boundaries of sovereign states, the conduct of international transactions is different from that of domestic trade. This study will examine the international business imperative; alliances in international business; the politics and law in international business; international economic integration, market transition and development.

\section{THE INTERNATIONAL BUSINESS IMPERATIVE}

Revolutionary changes in technologies have provided the mechanisms that propel the growth of international business. The intensification of competition at both domestic and international levels has driven firms to look beyond their domestic markets for new opportunities. The progressive removal of barriers to trade and capital movements has stimulated greater flows of exports, imports and foreign direct investment (FDI). Multinational enterprises have emerged as the key agents of international economic coordination. They provide the capability to generate innovations and deliver new goods and services to the market; they also provide the capability to exploit these technological advances at a global level, and they are a depiction of the capacity of international managerial coordination to operate efficiently across international boundaries. Crafts (2000) observed that the growing economic strength of the newly-industrializing countries (e.g. Taiwan, Hong Kong, Singapore, Korea) and the opening up of China and Eastern Europe have provided an additional stimulus to international business services.

\section{ALLIANCES IN INTERNATIONAL BUSINESS}

There are many organizations who act as the alliances in international business. Some of the most noted ones are the World Trade Organization and the International Monetary Fund (IMF). They are briefly described below:-

\section{(a) World Trade Organization (WTO)}

The World Trade Organization (WTO) is the only global international organization dealing with the rules of trade between nations. At its heart are the WTO agreements, negotiated and signed by the bulk of the 
world's trading nations and ratified in their parliaments. The goal is to help producers of goods and services, exporters, and importers conduct their business (Reid, 2000).

\section{International Monetary Fund (IMF)}

The International Monetary Fund is a specialized agency of the United Nations system set up by treaty in 1945 to help promote the health of the world economy. Its headquarter is in Washington, D.C. It is governed by its almost global membership of 184 countries.

The IMF is the central institution of the international monetary system - the system of international payments and exchange rates among national currencies that enables business to take place between countries.

It aims to prevent crises in the system by encouraging countries to adopt sound economic policies; it is also-as its name suggests-a fund that can be tapped by members needing temporary financing to address balance of payments problems. By uniting several economies in the North Western hemisphere, the alliances believe it can establish conditions in which trade would be most efficient. In order to implement such a strategy in the North Western hemisphere, it must be realized that there are quite a good number of companies required to make it all possible (Mussa, 2000).

\section{POLITICS AND LAW IN INTERNATIONAL BUSINESS}

Protestors believe that some of the biggest business owners want more and more autonomy from the government, and have in fact succeeded in blackmailing them into allowing them to implement the free trade.

By implementing free trade, is said that businesses that establish liberty to trade with whomever they want gain both power and profit. This kind of situation is something that is extremely dangerous to the 800 million people living in North, Central and South America. These same people produce an estimated CDN \$15 Trillion even though more than half of them live in poverty. If is feared that the alliances might have an immense influence on their lives and worsen their already pathetic standard of living (Wei, 2001).

Though these kinds of fears still prevail with the existence of the alliances, its merits must not be overruled. It should be remembered that products that are scarce or are not available would be freely available at affordable rates (Kluyver, 2001). The fact that labour is cheaper in economies outside the United States and Canada creates enormous opportunity for profit for investors. This is because of the fact that products produced where labor is cheaper means that they would be sold for greater profit in the investing countries. But this does not mean that only richer countries or investors would gain from such a venture. This is because of the fact that there would also be many more job opportunities created in countries that fall under the THE ALLIANCES.

In addition to such benefits there are numerous others that may be achieved under the agreement. In the December of 1994 in Miami this was the basic idea behind uniting the economies of the Western Hemisphere into a single free trade arrangement. Though the concept was initiated in 1994 when the FTAA's launching was planned for 2005, and this venture would certainly supersede NAFTA, as it encompasses many more countries in the North Western Hemisphere (Garrett, 1995).

The alliances such as the FTAA even has greater potential for efficient trade than the NAFTA, as is emphasized in the words of US Secretary of State Colin Powell: our objective with the FTAA is to guarantee control for North American businesses over a territory which stretches from the Arctic to the Antarctic, free access, over the entire hemisphere, without any difficulty or obstacle, for our products, services, technology and capital" (Ainger, 2002).

It is evident that there would be a surge in the US economy if the THE ALLIANCES were to be established. There is already so much zeal for its inception from the private sector which means that the economy would certainly be strengthened. Though there would not be heavy or extra taxes imposed on the private sectors but the fact that there would be many more businesses participating in the venture that the regular taxes collected would serve as a basis for more funds in the country.

In addition to the US gaining economically the poorer countries would also gain though their taxes would not be increased. This is because there would be many more people with jobs there, and businesses setup under the alliances would also provide more regular tax for their countries. It is because of this that their economy would also be ameliorated (Cox, Ronald W 1994).

Considering the number of people whose lives would be influenced by the alliances it must be realized that there would certainly be a very significant outcome. It is really up to governments to overview all the trade processes that would take place in countries under the alliances.

One cannot begin to imagine what would ensure if organizations really had enough autonomy to carry out their businesses independently. It is quite hard to believe that governments would be blackmailed by organizations to allow them more power and profit. This is because governments would not allow the country to be used for the sake private sector if the country did not stand to gain anything from a particular venture.

It is also quite hard to believe that there would be so many countries involved with the alliances that would be blackmailed by businesses. Governments surely would be more aware of the intimidating aspects of 
businesses and would not permit any kind of venture that would cause them or their people to lose power and independence.

The alliances are an agreement that is bent on ameliorating trading conditions in the North Western hemisphere, and therefore making these countries more and more independent of other countries that are greater distances. In this way these countries are also saving themselves a great deal of resources because of the distances and time spans being mitigated tremendously. Their markets too are large enough to host trade with in the North Western hemisphere, without them interacting with other continents. Independence of other countries with regard to trade seems to be of central importance in the alliances, along with the fact that there is immense scope for greater profit.

The poverty of a country can be defined as the total economic stability or instability it has. If defines the status of the individual and the country as well. Countries that are poor are likely to remain the same inequalities. This is often the trend that is followed in capitalist society. Most of the poor countries that are trying to apply democracy are the ones that seem to become victims of the same. It appears that richer countries can afford this form of government if the general standard of living is relatively higher than others (Gartside, 1987).

An example of this is the United States of America, where we see that there is also significant amount of poverty and unemployment. This country also has a high standard of living, so these effects are not that prominent. But, if we look at a country like India, we see that because the general standard of living is so low the whole country seems to be a poor one, and the majority of the population suffers.

At the same time, we must also compare the two as far as their defence budgets are concerned. This gives us a good idea of some of the reasons why poverty is so difficult to remove from there. Of course, though the international community is aware of the way that things have fallen into place against the favor of these poor countries, there is not much that can or will be done about the same. It is the international politics practiced today that keeps the poorer countries the way that they are so that they are not capable of developing themselves to a degree that will match the superpowers, which at one time ruled over them by force. Today, the same is seen and not much has changed because it all continues in the form of economic oppression.

According to Diaz (2001), we find that the incidence of poverty decreased between 1987 and 1998. The level of poverty in some regions of the world has gone extremely bad in the last decade or so, and this is largely due to the effect that free trade has had long with few other factors. But this is just one of the reasons for the same in countries where there is far too much freedom exercised with regard to trade. It is also said that far too many "persistent inequalities (in income and other measures)" are responsible for the poverty of the world to be in such bad shape. The economic growth and the rate of it as well as responsible for the condition that the world economy is in today.

\section{THE THEORY OF INTERNATIONAL TRADE AND INVESTMENT}

Trade is not only limited to commodities that some countries produce and others do not. Most countries sometimes import goods that they could produce cheaper than the countries from which they got them. Nigeria, for example, import refined petroleum even when it has three refineries at Port Harcourt, Warri and Kaduna. Most times, the refined petroleum which Nigeria imports, were imported from countries that are not oil producing, but it established refineries and having procured the crude oil product from Nigeria at cheaper rates, turned around to refine it and supply to Nigeria at higher cost. The principle or law of comparative cost, or comparative advantages in the theory of international trade is usually being advanced by countries involved relationship of this nature. This is because countries tend to concentrate on producing those things that give it the best return for any given investment of its productive resources and to improve its foreign relation with other country. The theory of international investment explains international capital movements in the contest of international production and trade. International investment creates international production and is integrated via international trade. Knowledge, know-how and technology are generally transferred between countries along with financial capital.

\section{INTERNATIONAL ECONOMIC INTEGRATION, MARKET TRANSITION AND DEVELOPMENT}

International economic integration, market transition and development are not new phenomenon. Geiersbach (2010) observed that some communication and trade took place between distant civilizations even in ancient times and since the travels of Marco Polo seven centuries ago, global economic integration - though trade, factor movements, and communication of economically useful knowledge and technology - has been on a generally rising trend. This process of globalization in the economic domain has not always proceeded smoothly, nor has it always benefited all whom it has affected. However, following the collapse of the Roman Empire or during the interwar period in this century, the degree of economic integration among different societies around the world has generally been rising. Indeed, during the past half century, the pace of economic 
globalization has been particularly rapid. With the exception of human integration, global economic integration today is greater than it ever has been.

Three fundamental factors have affected the process of economic globalization. Firstly, improvements in technology or transportation and communication have reduced the costs of transporting goods, services and factors of production and of communicating economically useful knowledge and technology. Secondly, the tastes of individuals and societies have generally, but not universally, favoured taking advantage of the opportunities provided by declining costs of transportation and communication through increasing economic integration. And thirdly, public policies have significantly influenced the character and pace of economic integration, although not always in the direction of increasing economic integration.

In Seattle, for example, there was a manifestation of popular opposition to globalization under the rules of free trade. What has been happening in Puerto Rico is a result of that same process in a specific national context. This is the country where the free trade model of development was implemented decades before it became the dominant global paradigm. For over 100 years, the history of Puerto Rican people has been dominated by the economic imperatives of the US, living under an evolving colonialism that has always manifested itself in significant socio-political environment. This strike made transitions in relation to international market integration difficult.

Also in Nigeria, all sectors of the oil and gas industry, allowed multinational companies to thrive in the environment, in spite of the various laws that prohibit foreigners or expatriates where there are qualified Nigerians in a particular field of specialization. Nigeria import over ninety percent of the oil and gas tools or equipments. Over-invoicing and tax evasion and so on, are common in Nigeria. Evidence shows that highly placed Nigerians collude with these multinational companies and foreigners to defraud the country.

\section{Conclusion}

Though globalization has taken place, and the rate at which trade should be taking place, it appears that the reverse has resulted. And this is largely due to the faulty policies that have been implemented by governments that have encouraged too much freedom. There is also a reason for this. The state of some of the poor countries is so bad that the educational sector is also in a pathetic condition. There are many people who are struggling to improve the literacy level too, but it is indeed a difficult task because of the lack of funds in these regions. In addition to this, those who do manage to obtain a good education do not want to waste their acquired knowledge within the same country, and hence, search for means to better their prospects abroad.

It is these people who do not realize the fact that their talents and capabilities are being exploited. They are given lucrative offers outside their own countries, which they do not refuse. As a result, exploitation does not end even if the individuals are educated, and the country itself continues to be led by less educated, shortsighted politicians that serve as an internal destructive force. This takes place because they have a lack of realization of the situation that they get into, and they know that they only have a short while to amass wealth while they are in power. Hence, the country sinks deeper in poverty.

\section{References}

[1]. Cox, Ronald W, 1994, Power and Profits: US Policy in Central America, Lexington: University Press of Kentucky.

[2]. Crafts, March 2000, "Globalization and Growth in the Twentieth Century", IMF Working Paper, WP/00/44, Washington, DC, International Monetary Fund.

[3]. Diaz, Jean, Latin American Perspectives 21 June 2001, csf.colorado.edu/lap.

[4]. Gartside, L, 1987, Commerce - A Guide to the Business World, London: Pitman Publishing.

[5]. Gbosi, Augustine N., 1999, Principles of International Trade: Theory and Policy, (Aba, Nigeria: Isaeco Press \& Ind. Ltd).

[6]. Kluyver, de, "Global Trade", The Political Imperative in International Business. 21 June, 2001. www.gmu.edu/departments/t-icp.

[7]. Mussa, Michael, 25 August, 2000, "Factors Driving Global Economic Integration", IMF Working Paper, Washington DC: International Monetary Fund.

[8]. Reid, Cynthia, 19 March, 1999, Journal of Multinational Financial Management. 21 June 2001, http/gort.ucad.edu/2010/129.

[9]. Sussman, Joshua 1997, "The International Financial Market, Organised Crime and International Law", US Department of Justice, 21 June 2001. www.usdoj.gov.

[10]. Wei, Annie, 21 June, 2001, International Business and Globalization. www.lancs.ac.uk/staff. 